\title{
PENGAMBILAN KEPUTUSAN ETIS DALAM NOVEL BURLIAN KARYA TERE LIYE: KAJIAN LITERASI MORAL
}

\author{
Akhmad Idris \\ Akhmadidris9@gmail.com \\ Universitas Negeri Surabaya, Jawa Timur
}

\begin{abstract}
This research is motivated by three things, namely 1) moral literacy which becomes an ability that needs to be considered in the 21 st century, 2) moral literacy which is used to make ethical decisions, and 3) Burlian novel which is one of the literary works that reflects moral literacy. This study aims to describe the ethical decision making in the novel Burlian by Tere Liye with the study of moral literacy. This research is a qualitative descriptive type. Data collection were taken through library techniques and data analysis techniques using content analysis techniques. The results of this study indicate that ethical decision making is based on three components of moral literacy, namely ethical sensitivity, ethical reasoning, and moral imagination. The pattern of the three components of moral literacy is ethical sensitivity as a form of ethical action, whereas ethical reasoning and moral imagination are the foundation of the ethical action.
\end{abstract}

Keywords: Ethical Decisions, Moral Literacy, Burlian Novel

\begin{abstract}
Abstrak: Penelitian ini dilatarbelakangi oleh tiga hal, yakni 1) literasi moral menjadi kemampuan yang perlu dipertimbangkan di abad 21,2) literasi moral digunakan untuk mengambil keputusan etis, dan 3) novel Burlian adalah satu di antara karya sastra yang mencerminkan literasi moral. Penelitian ini bertujuan untuk mendeskripsikan pengambilan keputusan etis dalam novel Burlian karya Tere Liye dengan kajian literasi moral. Penelitian ini berjenis deskriptif kualitatif. Teknik pengumpulan data menggunakan teknik pustaka dan teknik penganalisisan data menggunakan teknik analisis isi. Hasil penelitian ini menunjukkan bahwa pengambilan keputusan etis dilandasi oleh tiga komponen literasi moral, yakni kepekaan etika, penalaran etis, dan imajinasi moral. Pola tiga komponen literasi moral tersebut adalah kepekaan etika sebagai wujud tindakan etis, sedangkan penalaran etis dan imajinasi moral sebagai landasan dari tindakan etis tersebut.
\end{abstract}

Kata kunci: Keputusan Etis, Literasi Moral, Novel Burlian 
2 | Bahasa dan Seni: Jurnal Bahasa, Sastra, Seni, dan Pengajarannya

Volume 47, Nomor 1, Februari 2019

\section{PENDAHULUAN}

Literasi menjadi keterampilan abad 21 yang sedang berkembang pesat di Indonesia. Perkembangan tersebut ditandai dengan pembentukan Gerakan Literasi Sekolah, Gerakan Literasi Masyarakat, dan Gerakan Literasi Bangsa. Literasi tidak hanya terbatas pada kemampuan membaca dan menulis, tetapi juga mencakup kesadaran seseorang menggunakan kompetensi yang dimiliki dalam kehidupan. Dharma (2014: 121) menyebut literasi dengan istilah literasi fungsional. Fungsional berarti literasi yang berkaitan dengan berbagai fungsi dan keterampilan hidup. Oleh sebab itu, literasi berkembang menjadi lebih bervariasi, seperti literasi media, literasi digital, literasi komunikasi, literasi data, bahkan literasi moral. Tuana (2007: 364) menyebutkan bahwa literasi matematika dan membaca di Amerika lebih dikembangkan daripada literasi moral. Oleh sebab itu Tuana mengembangkan konsep literasi moral agar seseorang menggunakan kompetensi etis dalam kehidupannya.

Literasi moral digunakan untuk mengambil keputusan etis dalam situasi-situasi tertentu. Mengerjakan tugas dari sekolah dengan mengunduh tugas orang lain di Internet akan dihindari oleh seseorang yang memiliki kemampuan literasi moral. Penolakan terhadap hal tersebut disebabkan pemahaman bahwa menggunakan tugas orang lain untuk diri sendiri adalah tindakan yang tidak etis. Keterampilan moral adalah seperangkat kemampuan yang berkontribusi untuk membuat keputusan moral yang benar (Piderit, 2018: 221). Pengambilan keputusan moral yang benar dipengaruhi oleh tingkat keterampilan moral yang dimiliki. Ketika dihadapkan dengan situasi etis, keterampilan moral yang memadai menjadi kunci dari pengambilan tindakan etis. Oleh sebab itu, keterampilan moral perlu dikembangkan untuk memunculkan literasi moral agar penentuan tindakan terhadap situasi etis menjadi keputusan moral yang benar. Keterampilan moral pada dasarnya sama dengan keterampilan sosial. Keterampilan sosial diartikan sebagai kemampuan untuk beradaptasi dan mengenali kemampuan diri sendiri dalam berinteraksi dengan masyarakat, termasuk membuat keputusan, berkomunikasi, dan bekerja sama dalam bermasyarakat; sedangkan keterampilan moral diartikan sebagai kemampuan yang berupa kepekaan, keterbukaan pemikiran, memaafkan, dan bertanggung jawab.

Tuana (2007: 364) menyebutkan tiga kemampuan yang harus dikembangkan untuk menjadi seseorang yang moral literate, yakni 1) kepekaan etika, 2) penalaran etis, dan 3) imajinasi moral. Tiga kemampuan tersebut saling berhubungan dan tidak bisa dipisah dalam pembentukan literasi moral. Menjadi manusia yang literate bukan proses alamiah, tetapi proses yang dikembangkan. Herman (1997: 313) menyebutkan bahwa pelaku moral menjadi literate (kemampuan atau keterampilan untuk menggunakan pengetahuannya) bukan proses organik, tetapi proses yang disengaja. Sepaham dengan Herman, Bennett (1986: 6) juga menyebutkan bahwa literasi moral tidak lahir dengan pengetahuan, tetapi dengan proses pembelajaran. Kemampuan tersebut tidak berkembang seperti kondisi fisik manusia yang tumbuh secara alamiah, tetapi kemampuan tersebut secara sengaja dikembangkan dengan memaksimalkan kompetensi yang dimiliki. Sniras dan Malinauskas (2005: 386) menjelaskan tentang keterampilan moral anak-anak di masa sekolah. Sniras dan Malinauskas menyebutkan bahwa keterampilan moral yang perlu diterapkan adalah menghibur teman yang bersedih, menolong yang mengalami kesulitan, tidak berpura-pura baik (munafik), tidak curang dalam melakukan perbuatan, tidak mempermalukan teman di depan temanteman lain, tidak membalas dendam ketika disakiti oleh teman, menjaga mulut dari perkataan yang menyakiti perasaan teman lain, dan berani bertanggung jawab atas tindakan yang telah dilakukan. Literasi moral bertujuan untuk mengembangkan keterampilan yang dibutuhkan 
untuk menjadi manusia yang lebih baik. Clifford (2011: 127) menjelaskan bahwa standar dari lterasi moral adalah Derivability, artinya tindakan-tindakan yang dilakukan berdasar pada prinsip-prinsip moral. Prinsip-prinsip moral tersebut harus bersifat preskriptif, berdasar pada kejujuran, dan justifikasi.

Kepekaan etika adalah kemampuan penting dalam pengembangan literasi moral. Tuana (2007: 366) menyebutkan tiga komponen utama dalam kepekaan etika, yakni 1) kemampuan untuk menentukan keterlibatan isu-isu etis dalam suatu situasi, 2) kesadaran intensitas moral situasi etis, dan 3) kemampuan untuk mengidentifikasi kebaikan moral atau nilai-nilai yang mendasari situasi etis. Pemahaman tentang nilai-nilai kebaikan memberikan pola pikir yang baik untuk memeriksa situasi tertentu dan menentukan apakah situasi tersebut melibatkan masalah-masalah etis atau tidak. Pendapat Tuana di atas diperkuat oleh pandangan Poespoprodjo (1999: 89) yang menjelaskan bahwa perbuatan muncul dari suatu motif dan diarahkan pada suatu tujuan tertentu. Selanjutnya, kehendak untuk melakukan perbuatan adalah kemampuan yang buta, bukan kemampuan untuk mengerti. Manusia tidak dapat bertindak kecuali jika dicerahkan dengan pengetahuan atau pemahaman. Sebagai contoh, seseorang tidak akan melakukan perbuatan yang adil jika orang tersebut tidak memahami pengertian tentang adil.

Keterampilan lain yang perlu dikembangkan dalam literasi moral adalah kemampuan penalaran etis. Tuana (2007: 368) menyebutkan bahwa kemampuan penalaran etis juga mencakup tiga komponen yang berbeda. Tiga komponen tersebut adalah 1) Pemahaman tentang berbagai kerangka etis, 2) Kemampuan untuk mengidentifikasi, menilai keabsahan fakta-fakta yang relevan dengan situasi etis, dan menilai setiap kesimpulan dari fakta-fakta tersebut, dan 3) Kemampuan untuk mengidentifikasi dan mengevaluasi nilai-nilai seorang individu atau kelompok yang relevan dengan masalah etis yang dipertimbangkan. Clifford (2011: 129-131) memasukkan pemahaman terhadap kerangka etis pada Justification. Justifikasi merupakan satu di antara tiga syarat dari prinsip moral yang teridentifikasi. Dua syarat sisanya adalah preskriptif dan jujur dalam mengaplikasikannya. Preskriptif berarti suatu tidakan moral harus memberikan petunjuk, jelas dan fleksibel. Contoh sederhana untuk menjelaskan maksud dari fleksibel adalah ketika manusia membunuh, tidak berarti ia buruk. Membunuh untuk menghukum merupakan suatu hal yang dibenarkan. Di daerah Timur Tengah dikenal dengan hukuman Qishash, yakni membunuh harus dibalas membunuh juga.

Keterampilan dalam pengembangan literasi moral yang terakhir adalah pengembangan imajinasi moral. Johnson (1993: 202) menjelaskan bahwa imajinasi moral merupakan kemampuan melihat secara imajinatif berbagai kemungkinan atas tindakan dalam situasi tertentu, merancang pertolongan potensial, dan membatalkan hal yang mungkin diakibatkan oleh situasi tertentu. Imajinasi moral berhubungan dengan perpaduan afektif dan proses rasional yang berkontribusi untuk imajinasi. Tuana (2007: 375) menjelaskan bahwa imajinasi moral mencakup kekayaan kemampuan. Hal ini termasuk empati terhadap perasaan dan keinginan yang lain. Imajinasi moral juga bisa dikatakan sebagi kemampuan berpikir "di luar kotak" dan mempertimbangkan alternatif yang kreatif. Imajinasi morupakan hal yang paling fundamental untuk mengapresiasi sebagai agen etika. Pengalaman hidup yang terjadi sebagai agen etika tidak hanya sebagai penerimaan rasional sebagai bentuk tanggung jawab dari konsekuensi atas tindakan, tetapi sebuah pengalaman yang dilakukan dengan tanggung jawab.

Karya sastra dapat dijadikan sebagai hiburan dan nasihat hidup. Sesuai dengan yang disampaikan oleh Wellek \& Werren (2016: 23) yang mengatakan bahwa fungsi seni (sastra) adalah dulce dan utile. Sastra adalah keindahan sekaligus pesan. Satra dapat digunakan 
sebagai sarana untuk menikmati keindahan melalui teks dan mengambil nasihat-nasihat kebaikan dari teks tersebut. seperti contoh kisah Malin Kundang yang diceritakan oleh Guru atau Orang Tua kepada siswa atau anaknya bertujuan untuk memberikan hiburan kepada siswa atau anak. Hiburan bagi siswa berarti dongeng atau cerita rakyat (sastra) menjadi satu di antara favorit siswa selain materi pelajaran matematika, IPA, dan lain-lain. Hiburan bagi anak berarti dongeng atau cerita sebelum tidur yang disampaikan oleh Ibu atau Ayah. Kisah Malin Kundang selain sebagai hiburan, juga digunakan sebagai sarana memberikan nasihat atau amanat dari cerita tersebut. Nasihat yang terdapat dalam kisah Malin Kundang adalah akibat anak yang durhaka terhadap orang tua. Jadi, karya sastra dapat dijadikan sebagai satu di antara sarana mengembangkan kemampuan literasi moral. Novel Burlian karya Tere Liye adalah satu di antara novel yang mencerminkan kemampuan literasi moral. Niam Masykuri, Editor in Chief majalah Parents Guide mengatakan bahwa novel Burlian karya Tere Liye mengisahkan kebaikan tanpa perlu menggurui. Kemampuan literasi moral dalam novel Burlian ditunjukkan ketika Burlian menyadari kasih sayang Mamak melalui pengembangan penalaran etis, imajinasi moral, dan kepekaan etika. Tiga kemampuan tersebut yang membentuk seseorang memiliki kemampuan literasi moral.

Berdasar hal-hal yang telah disebutkan, penelitian ini bertujuan untuk menjelaskan pengambilan keputusan etis dalam novel Burlian karya Tere Liye dengan kajian Literasi Moral yang meliputi kepekaan etika, penalaran etis, dan imajinasi moral.

\section{METODE}

Jenis penelitian ini adalah deskriptif kualitatif yang bertujuan untuk mendeskripsikan pengambilan keputusan etis dalam novel Burlian karya Tere Liye dengan kajian Literasi Moral. Penelitian ini menggunakan kajian literasi moral untuk menjelaskan kepekaan etika, penalaran etis, dan imajinasi moral dalam novel Burlian, kemudian disatukan menjadi satu kesatuan tentang pengambilan keputusan etis. Sumber data dalam penelitian ini adalah novel Burlian karya Tere Liye karena kesesuaian isi novel dengan tujuan penelitian ini, yakni pengambilan keputusan etis. Teknik pengumpulan data menggunakan teknik pustaka, oleh sebab itu data dalam penelitian ini berupa narasi dan dialog antartokoh yang menjelaskan pengambilan keputusan etis terkait kepekaan etika, penalaran etis, dan imajinasi moral. Teknik penganalisisan data menggunakan teknik analisis isi untuk mengungkap pesan (pengambilan keputusan etis) dalam novel Burlian karya Tere Liye.

\section{HASIL DAN PEMBAHASAN}

Pengambilan keputusan etis dalam novel Burlian karya Tere Liye tercermin pada tindakan-tindakan etis dalam keluarga, persahabatan, dan masyarakat. Pengambilan keputusan etis dalam tindakan-tindakan tersebut membutuhkan kemampuan kepekaan etika, penalaran etis, dan imajinasi moral. Sejalan dengan yang disampaikan oleh Tuana (2007: 364) bahwa pengembangan kemampuan literasi moral melipatkan tiga hal yakni, ethics sensitivity (kepekaan etika), ethical reasoning skills (penalaran etis), dan moral imagination (imajinasi moral). 


\section{Tindakan Etis dalam Keluarga}

Pengambilan keputusan etis dalam masalah keluarga ditunjukkan oleh Burlian ketika memutuskan untuk berhenti bolos sekolah. Tindakan bolos sekolah yang dilakukan oleh Burlian diketahui oleh Ibunya (Mamak), sehingga Mamak membiarkan Burlian tidak bersekolah dan mengajaknya pergi ke kebun mengambil kayu bakar. Keputusan Burlian untuk berhenti disebabkan oleh kombinasi kepekaan etika, penalaran etis, dan imajinasi moral yang dimiliki oleh Burlian tentang bolos sekolah. Kepekaan etika yang ditunjukkan oleh Burlian adalah memilih sekolah daripada bolos. Hal tersebut ditunjukkan oleh data 1

1) "Kata Mamak, kau disuruh ikut ke kebun lagi hari ini". Ayuk Eli mendesis.

Aku tergagap. Apa? Mengabaikan seluruh rasa sakit di tubuh aku lompat dari ranjang, bergegas menyambar handuk. Tidak mau. Hari ini aku sekolah saja. (Liye, 2017: 28)

Data 1 menunjukkan bahwa Burlian menyadari masalah yang sedang dihadapinya, sehingga Burlian memilih untuk sekolah daripada bolos dan pergi ke kebun lagi bersama Mamak. Tuana (2007: 366) menyebutkan bahwa satu di antara komponen kepekaan etika adalah mampu menyadari intensitas moral. Data 1 menjadi bukti kemampuan Burlian menyadari kelayakan tindakan berdasarkan intensitas moral, yakni memilih bersekolah daripada bolos. Burlian menyadari tindakan yang seharusnya lebih dipilih dan tindakan yang seharusnya ditinggal.

Kepekaan etika yang dilakukan oleh Burlian didasari atas penalaran etis dan imajinasi moral terhadap efek atau akibat dari bolos sekolah. Penalaran etis Burlian terdapat pada pemahaman Burlian tentang dampak yang ditimbulkan dari bolos sekolah. Pemahaman tersebut dapat dilihat pada data 2

2) Tidak mau. Hari ini aku sekolah saja, juga besok-besoknya, lusa-lusanya. Tidak mau. Kalau begini urusannya, jelas lebih enak sekolah dibandingkan dihukum seharian Mamak. Bahkan Bapak yang sedang berdiri di belakang Ayuk Eli, tertawa gelak melihat raut mukaku. (Liye, 2017: 28)

Burlian memahami bahwa bersekolah lebih baik dan menyenangkan daripada berangkat ke kebun untuk mencari kayu bakar seharian, karena dihukum oleh Mamak. Data 2 menunjukkan pemahaman Burlian terhadap akibat dari tindakan yang telah dilakukan. Burlian mampu menilai fakta yang relevan dengan situasi yang dialami. Burlian mampu memahami bahwa penghuni rumah yang tidak bersekolah bekerja untuk memenuhi kebutuhan keluarga, yakni bekerja di kebun. Penalaran etis Burlian menyadarkannya untuk tidak mengulangi perbuatan bolos sekolah. Penalaran etis dilandasi oleh pemahaman terhadap kerangka etis. Clifford (2011: 129-131) menyebutkan bahwa satu di antara prinsip tindakan etis (prinsip moral) adalah Justification. Justifikasi yang dimaksud oleh Clifford adalah pemahaman terhadap kerangka-kerangka etis, seperti deontologis, utilitarian, atau etika kepedulian.

Imajinasi moral juga mendukung Burlian untuk memiliki kemampuan kepekaan etika. Tuana (2007: 375) menjelaskan bahwa imajinasi moral merupakan kemampuan out of the box untuk mempertimbangkan alternatif kreatif. Imajinasi moral berhubungan dengan kemampuan membayangkan akibat dan konsekuensi dari tindakan etis, sehingga dapat memilih alternatif memlalui pemikiran yang kreatif. Imajinasi moral yang dilakukan Burlian ditunjukkan ketika Burlian membayangkan kemungkinan yang terjadi jika Burlian memprotes hukuman yang diberikan Mamak. Imajiansi moral ditnjukkan oleh data 3. 
6 | Bahasa dan Seni: Jurnal Bahasa, Sastra, Seni, dan Pengajarannya

Volume 47, Nomor 1, Februari 2019

3) Kami mulai mengerti aturan mainnya. Ini jelas bukan kesenangan seperti yang kami duga awalnya. Ini justru hukuman karena kami bolos sekolah dan sebagai pihak yang dihukum, protes hanya akan membuat hukuman jadi lebih berat. (Liye, 2017: 25)

Data 3 menunjukkan kemampuan Burlian dalam membayangkan hal yang akan terjadi atas protes, yakni hukuman yang lebih berat. Hukuman seharian bolak-balik dari kebun ke rumah bagi Burlian adalah hukuman yang berat, karena sebelumnya belum pernah diberi hukuman seperti itu oleh Mamak. Kemampuan imajinasi moral Burlian membantunya untuk tetap menuruti dan mengikuti aturan main Mamak.

Berdasarkan imajinasi moral, penalaran etis, dan kepekaan etika yang dimiliki oleh Burlian; pengambilan keputusan etis dilakukan dengan baik oleh Burlian. Burlian memutuskan akan terus bersekolah dan tidak akan membolos lagi. Kemampuan literasi moral yang dimilki Burlian membuatnya berhasil mengambil keputusan etis.

\section{Tindakan Etis dalam Persahabatan}

Persahabatan menjadi hubungan yang sering memunculkan pengambilan keputusan etis. Tindakan etis dalam persahabatan dalam novel Burlian karya Tere Liye terdapat dalam kisah persahabatan Burlian dan Ahmad. Burlian digambarkan sebagai anak yang spesial karena memiliki pemahaman yang baik atas sesuatu, sedangkan Ahmad digambarkan sebagai anak yang berkulit hitam, dekit, berambut keriting, dan sering dimanfaatkan dan dihina oleh teman-temannya. Hal tersebut terjadi karena Ahmad sosok yang pemalu. Pengambilan keputusan etis yang dipilih oleh Burlian adalah menjadikan Ahmad sebagai teman baik dan membelanya ketika Ahmad dihina. Tindakan etis Burlian dipengaruhi oleh kemampuan kepekaan etika, penalaran etis, dan imajinasi moral yang dimilikinya. Kepekaan etika Burlian terlihat ketika Burlian membela Ahmad yang dihina "Anak Haram" oleh kakak kelas. Kejadian tersebut ditunjukkan oleh data 4.

1) "Mereka yang mulai duluan, Pak". Aku berteriak tidak mau kalah.

"Berhenti, Burlian!”. Pak Bin menarik lenganku.

"Mereka menghina Ahmad anak haram, Pak. Mereka yang mulai duluan". Aku berusaha melepas cengkeraman Pak Bin. (Liye, 2017: 48)

Burlian pada data 4 menunjukkan kesadarannya terhadap situasi yang terjadi dengan Ahmad. Burlian tidak gentar dan takut sedikitpun terhadap kakak kelas, meskipun secara fisik Burlian lebih kecil. Burlian menyadari bahwa menghina seseorang dengan sebutan "anak haram" adalah hal yang tidak etis, apalagi jika hal tersebut adalah fitnah. Kepekaan etika yang dilakukan oleh Burlian dilandasi oleh penalaran etis dan imajinasi moral tentang fakta dari Ahmad. Data 4 sesuai dengan kompenan kepekaan etika yang disebutkan oleh Tuana (2007: 366) yaitu kemampuan untuk menyadari keterlibatan masalah etis dalam situasi-situasi etis. Kesadaran Burlian terhadap "hinaan terhadap orang lain adalah hal yang tidak etis" membuatnya berhasil menentukan tindakan etis.

Penalaran etis terhadap fakta dari Ahmad yang ditunjukkan oleh Burlian adalah ketulusan Ahmad terhadap keluarganya. Ahmad tidak bisa bermain dengan teman-temannya dan cenderung pemalu disebabkan Ahmad memiliki kewajiban yang tidak bisa ditinggal di rumah. Hal tersebut ditunjukkan oleh data 5 .

2) Aku meletakkan gelas yang sudah kosong. Terdiam. Kerongkonganku memang terasa segar kembali, tapi ada sesuatu yang tiba-tiba mencelup lebih dingin hatiku. Aku 
mengerti sekarang, kenapa Ahmad selalu bergegas pulang dari sekolah, tidak pernah terlihat bermain bersama yang lain, pendiam dan lebih sibuk dengan dunianya sendiri, karena dia memang sibuk bekerja membantu Ibunya. (Liye, 2017: 47)

Data 5 menunjukkan kemampuan penalaran etis Burlian dalam memahami fakta yang terdapat dalam keseharian Ahmad. Ungkapan mencelup lebih dingin hatiku merefleksikan kesadaran Burlian terhadap fakta bahwa Ahmad adalah seseorang yang mulia dan berhati baik. Burlian memahami bahwa Ahmad tidak bisa bermain dengan teman-temannya bukan karena Ahmad tidak berkenan bermain, tetapi Ahmad lebih memilih membantu Ibunya daripada bermain untuk dirinya sendiri. Penalaran etis Burlian mendorongnya untuk mengambil tindakan etis, yakni keinginan menjadi teman baik Ahmad.

Tindakan etis yang dilakukan oleh Burlian juga didukung oleh imajinasi moral. Burlian mampu membayangkan apa yang dikatakan oleh Bapak tentang kehebatan Ahmad. Imajinasi moral tersebut terdapat pada data 6 .

3) Teringat Bapak dalam sebuah kesempatan pernah bilang: "bayangkan...kalian bayangkan sepuluh tahun yang akan datang, mimpi itu boleh jadi hasilnya menakjubkan... Anak itu akan menjadi kebanggan kita. Semua orang akan membicarakannya. Anak itu sungguh akan membuat malu Bapaknya yang tidak tahu diri pergi begitu saja meninggalkannya". (Liye, 2017: 63-64)

Burlian membayangkan kemampuan sepak bola Ahmad. Ahmad yang pada awalnya dipandang remeh oleh masyarakat karena hitam, pendiam, dan tidak populer; sekarang telah menjadi idola baru di kampung karena bakat sepak bola yang menakjubkan. Burlian membayangkan sepuluh tahun yang akan datang Ahmad akan membuat bangga seluruh penduduk kampung dan menjadi sangat populer. Imajinasi moral yang dilakukan Burlian mendorongnya untuk menjadikan Ahmad sebagai teman baiknya, karena meskipun Ahmad pendiam, hitam, dan dekil; Ahmad memiliki keistimewaan yang tidak dimiliki kebanyakan orang.

Kepekaan etika, penalaran etis, dan imajinasi moral yang dimiliki oleh Burlian sebagai komponen literasi moral; membuatnya mampu mengambil keputusan etis. Saat kebanyakan orang memilih untuk mengucilkan Ahmad, tidak menganggap Ahmad ada, bahkan menghina Ahmad; Burlian memilih untuk melindungi Ahmad dan menjadikan Ahmad sebagai teman baiknya. Tindakan etis yang dipilih Burlian disebabkan pengembangan yang baik terhadap kepekaan etika, penalaran etis, dan imajinasi moral.

\section{Tindakan Etis dalam Masyarakat}

Manusia sebagai makhluk sosial memerlukan pengambilan keputusan etis dari setiap tindakan yang diambil agar tetap terjalin hubungan yang harmonis dengan masyarakat. Tindakan etis dalam novel Burlian tidak hanya dilakukan oleh Burlian, tetapi juga dilakukan oleh beberapa tokoh lain. Di antaranya adalah Pak Bin, Guru sekolah dasar Burlian dan kawan-kawan. Pengambilan keputusan etis yang ditunjukkan oleh Pak Bin adalah keyakinan Pak Bin untuk tidak berhenti percaya terhadap janji kehidupan yang lebih baik dengan bersekolah. Keputusan etis Pak Bin didukung oleh kepekaan etika, penalaran etis, dan imajinasi moral yang dimiliki oleh Pak Bin. Kepekaan etika ditunjukkan oleh pak Bin ketika menanyakan satu di antara muridnya yang tidak masuk sekolah. Kejadian tersebut ditunjukkan oleh data 7.

1) “Munjib... ada yang tahu Munjib kenapa tidak masuk hari ini?’. Pak Bin melepas kaca mata kusam miliknya, menatap ke seluruh kelas. 
8 | Bahasa dan Seni: Jurnal Bahasa, Sastra, Seni, dan Pengajarannya

Volume 47, Nomor 1, Februari 2019

Kami saling toleh satu sama lain, mengangkat bahu. Tidak tahu.

"Tadi pagi ada di depan rumahnya, Pak. Tapi sepertinya dia tidak hendak

berangkat sekolah. Mana ada orang ke sekolah sambil membawa penyadap karet dan keranjang rotan". Salah seorang kawan memberikan informasi.

“Kau sempat menegurnya?". (Liye, 2017: 143)

Kepekaan etika Pak Bin ditunjukkan oleh pertanyaannya dan keingintahuannya terhadap kondisi satu di antara siswanya yang tidak masuk sekolah. Ketika Pak Bin mengecek presensi siswa Pak Bin juga bertanya alasan siswa yang tidak masuk. Pak Bin juga menginstruksikan seluruh siswanya agar saling mengingatkan untuk tetap bersekolah. Kepekaan etika yang ditunjukkan Pak Bin membantu Pak Bin mengambil keputusan etis, yakni keyakinan untuk tetap mengajar dengan kondisi apapun.

Kepekaan etika Pak Bin juga didukung oleh panalaran etis dan imajinasi moral. Mutmainnah \& Iswarini (2015: 9) menyebutkan bahwa penalaran etis memiliki dampak positif terhadap sensitivitas etis (dalam penelitian ini disebut sebagai "kepekaan etika). Penalaran etis Pak Bin terjadi ketika menyebutkan alasan tidak menutup sekolah meskipun muridanya berjumlah kurang dari sepuluh. Kisah tersebut dapat dilihat pada data 8 .

2) "Katanya kalau murid di SD kurang dari sepuluh sekolah akan ditutup, Pak"?

"Kata siapa?". Pak Bin tertawa. "Kau jangan mendramatisir cerita, Burlian".

"Katanya di kampung lain begitu, Pak. Kurang dari sepuluh, sekolahnya ditutup". Aku berusaha mensejajari langkah Pak Bin yang panjang-panjang.

"Itu berlebihan... Bagi siapa saja yang mengaku mencintai mengajar, jangankan sepuluh atau sembilan, tinggal satu murid pun sekolahan tetap terus". (Liye, 2017: 146)

Data 8 menunjukkan kemampuan Pak Bin dalam memahami fakta yang relevan dengan situasi penutupan sekolah. Kepekaan etika yang dimiliki Pak Bin dilandasi oleh pemahaman yang baik terhadap makna mengajar. Pak Bin memahami bahwa siapapun yang benar-benar mencintai mengajar tidak akan mempertimbangkan jumlah siswa yang mau belajar. Selama masih ada yang ingin belajar, meskipun hanya satu siswa; pembelajaran akan tetap berlanjut. Pemahaman tersebut yang dipegang oleh Pak Bin, sehingga Pak Bin memeiliki kepedulian yang tinggi terhadap siswanya yang tiba-tiba tidak masuk sekolah.

Imajinasi moral menjadi faktor pendukung selain penalaran etis dalam mewujudkan kepekaan etika Pak Bin. Imajinasi moral dapat dilihat dalam jawaban Pak Bin terhadap pertanyaan Bapak Munjib tentang kegunaan sekolah. Jawaban tersebut dapat dilihat pada data 9.

3) “Buat apa sekolah, Bin?”. Bapak Munjib yang menjawab, dengan intonasi sedikit ketus.

Pak Bin tersenyum, diam sebentar, dia berpengalaman sekali urusan ini, "Dengan sekolah Munjib akan punya masa depan yang lebih baik, Pak Jaen. Dia punya ijazah, bisa ----“. (Liye, 2017: 147)

Jawaban Pak Bin menunjukkan kemampuan Pak Bin membayangkan kemungkinankemungkinan dan harapan yang lebih dengan bersekolah. Sekolah dapat memberikan janji masa depan yang lebih baik. Kemampuan imajinasi moral Pak Bin dan penalaran etisnya mendorong Pak Bin untuk peduli terhadap pendidikan anak-anak di kampung Burlian, tepatnya di Bukit Barisan. 
Pengambilan keputusan etis yang dilakukan oleh Pak Bin dilandasi oleh tiga komponen utama pengembang literasi moral, yakni kepekaan etika, penalaran etis, dan imajinasi moral. Kepedulian Pak Bin terhadap pendidikan siswa-siswanya, pemahaman yang baik Pak Bin terhadap hakikat mengajar, dan bayangan-bayangan atau harapan-harapan terhadap janji kehidupan yang lebih baik dengan bersekolah; membuat Pak Bin memutuskan untuk tidak pernah berhenti percaya dan yakin terhadap janji kehidupan yang lebih baik dengan bersekolah.

\section{SIMPULAN}

Berdasar pada hasil analisis dan pembahasan dapat disimpulkan bahwa Pengambilan keputusan etis dalam novel Burlian karya Tere Liye dilandasi oleh kepekaan etika, penalaran etis, dan imajinasi moral yang tercermin pada tindakan etis dalam keluarga, persahabatan, dan masyarakat. Pola pengambilan keputusan etis adalah kepekaan etika sebagai wujud tindakan etis, sedangkan penalaran etis dan imajinasi moral sebagai landasan dari tindakan etis tersebut.

\section{DAFTAR RUJUKAN}

Bennett, William. J. 1986. Moral Literacy and The Formation of Character. Washington DC: Departement of Education.

Clifford, Michael. 2011. Moral Literacy. Teaching Ethics, Spring: P. 125-141.

Dharma. 2014. Boom Literasi Menjawab Tragedi Nol Buku. Surabaya: Revka Petra Media. Herman, Barbara. 1997. Moral Literacy. Stanford: Stanford University.

Iswarini, Ega Megarina., \& Mutmainah, Siti. 2015. Pengaruh Penalaran Etis dan Faktirfaktor Pribadi Terhadap Sensitivitas Etis pada Mahasiswa Akuntansi. Diponegoro Journal Of Accounting, Vol. 2, No. 1. P. 1-11.

Johnson, M. 1993. Moral Imagination. Chicago: University of Chicago Press.

Liye, Tere. 2017. Burlian Serial Anak-anak Mamak. Jakarta: Penerbit Republika.

Piderit, John J. 2015. Basic Moral Skills. Oxford Scholarship Online. Oxford University Press. Doi: 9780199793273.003 .0027

Poespoprodjo, W. 1999. Filsafat Moral Kesusilaan dalam Teori dan Praktek. Bandung: CV Pustaka Grafika.

Sniras \& Malinauskas. 2005. Moral Skills Of School Children. Social Behaviour and Personality. Vol. 33, No. 4, January 2005, P. 383-390.

Tuana, Nancy. 2007. Conceptualizing Moral Literacy. Journal of Educational Administration. Vol. 45, No. 4, June 2007, P. 364-378.

Wellek, Rene \& Warren, Austin. 2016. Teori Kesusatraan. (Budianta, Melani). Jakarta: PT. Gramedia 